\title{
An examination of the relationship between secondary school students' abstract thinking skills, self-efficacy perceptions and attitudes towards mathematics
}

\author{
Ahmet Şükrü ÖZDEMİR \\ Prof. Dr. Marmara University, Faculty of Education, Department of Mathematics and \\ Science Education, Istanbul, Turkey \\ ORCID: 0000-0002-0597-3093
}

\author{
Sinan KARAŞAN \\ Mathematics Teacher, Ministry of Education, Bartin, Turkey \\ ORCID: 0000-0002-5611-853X
}

\author{
Muhammet SAHAL ${ }^{1}$ \\ Research Assistant. Yildiz Technical University, Faculty of Education, Department of \\ Mathematics and Science Education, Istanbul, Turkey
}

ORCID: 0000-0003-3625-2456

Article history

Received:

15.09.2020

Received in revised form: 19.12.2020

Accepted:

23.12.2020

Key words:

Mathematics education; Abstract thinking skills; Self-efficacy;

Attitude;

Boarding school
This study aims to examine whether there is a relationship between abstract thinking skills, self-efficacy perceptions and attitude towards mathematics and how these variables predict mathematics achievement. The study was conducted with 198 eighth-grade students who were selected by random sampling and the relational screening model was used. For data collection, the tools of "Abstract Thinking Test in Mathematics", "Self-Efficacy Perception Scale towards Mathematics", "Mathematics Attitude Scale" and Mathematics course notes of students were resorted to. According to the findings, it was concluded that there were significant relationships between students' abstract thinking skills, self-efficacy perceptions and attitudes towards mathematics, and these variables explained $37 \%$ of the variance in mathematics achievement. There was no significant difference in mathematics achievement between the groups according to the type of school, while it was found that the scores of the students' abstract thinking skills, attitude towards mathematics and self-efficacy perceptions differed in favor of the students studying in non-boarding secondary school. In addition, no significant difference was observed between the groups in terms of students' mathematics achievement according to their boarding status. It was found that there were significant differences in terms of the other three variables. Suggestions were made to increase mathematics achievement, especially in boarding secondary schools, and it was also offered to increase the feasibility of the environment of the boarding secondary schools.

1 Correspondency: msahal@yildiz.edu.tr 


\section{Introduction}

Today, mathematics education aims to bring up individuals who are doing research, questioning, communicating effectively, and using the forms of mathematical thinking effectively in both daily life and professional life. Academic success is one of the important indicators in determining whether students have reached the determined goals in the education processes at schools, because it is also one of the important predictors for students' success both in their ongoing education and their future after the school education ends (Casillas, Robbins, Allen, Kuo, Hanson \& Schmeiser, 2012; OECD, 2007).

It is stated that individual characteristics are as important as the cognitive skills such as problem solving, reasoning, communication and correlation (National Council of Teachers of Mathematics [NCTM], 2000) among the factors affecting students' academic success in mathematics (Akdemir, 2006; Akyuz, 2014; Usher, 2009). In other words, students' academic success depends on many cognitive and affective factors (Yurt \& Sunbul, 2014). In this context, students' abstract thinking skills (ATS) (Kablan \& Suzer Ugur, 2020), self-efficacy perceptions (SEP) (Alci et al, 2010; Falco, 2019) and their attitudes towards mathematics (ATM) (Demir \& Kilic, 2010; Peker \& Mirasyedioglu, 2003, Primi et al., 2020) are seen as important components that affect academic success in mathematics education.

It can be said that mathematical thinking skills should be developed in the first place in order to develop skills such as mathematical communication, problem solving, mathematical correlation, and effective use of technology. Mathematical thinking is an effective use of the rules and processes to achieve a certain result in a mathematical situation (Yesildere, 2006). For mathematics educators, the structuring of mathematical thoughts such as concepts, strategies or processes takes place with abstraction (Dreyfus, 2020; Ozdemir \& Gur, 2011). Van Oers (1998) has defined abstraction as a process of scrutinizing a thought which is in a constant development within its own context again and again. Piaget (2001) approached abstraction in two types; "experimental abstraction", which is distinguishing of objects in terms of common properties, and "reflective abstraction", which is a person's ability to think about his/her own actions at a high level or to combine these thoughts with their existing schemes. When the different definitions in the literature are analyzed, there is a consensus that the abstraction is a generalization that is reached through the recognition of the common points of more than one example, is a rise up that is achieved from the lowest concrete levels to the high levels of abstract thought, and a process that is realized independent from the conditions surrounding the environment (Ozmantar, 2005). Abstract thinking skills include skills such as establishing cause and effect relationships, research and constant questioning, awareness of the concept depth, and anticipation of some things (Agaç, 2013). The mathematics curriculum also emphasizes the importance of developing students' abstract thinking skills (MoNE, 2018). The role of abstract thinking skill in mathematics education is vital (Kablan \& Suzer Ugur, 2020). It is possible to reach generalizations which is a high level skill in mathematics with abstract thinking skill (Agaç, 2013). In other words, solving problems requiring high level mathematical thinking skills becomes easier with abstract thinking, and the gains obtained solving such problems can be used to solve new problems. In light of this information, it is realized how important abstract thinking skill is in the interpretation of mathematical concepts and relationships.

Self-efficacy is one of the affective structures that have a strong relationship with student success and learning in mathematics (Pantziara, 2016). Self-efficacy perception is the belief of an individual in developing himself/herself by organizing his/her own skills (Hoy \& Wollfolk, 1993). Self-efficacy for mathematics is the self-assessment of whether s/he has the necessary 
knowledge and skills to successfully fulfill a particular mathematical task or problem (Hackett \& Betz, 1989). Self-efficacy, which is also defined as the individual's personal belief in planning and managing the actions required in the process of achieving his/her goals (Bandura, 1997). It is one of the powerful components in predicting school success (Schunk, 1987; Zuffiano et al., 2013). Because it is thought that the person who has a high self-efficacy belief about a profession will perform that action with an internal motivation without the need for an external motivation. (Ayguner, 2016; Celik, 2012). If students believe that they have the skills and beliefs required to perform a task, they will be more likely to be eager, express their determination, and demonstrate the desired behavior to realize this task. However, it has been stated that self-efficacy perception is an effective predictor component in the cognitive, affective, motivational and selection processes of the individual (Bandura, 1997). Mathematics curriculum includes affective objectives such as "students will be eager to learn math, enjoy engaging in mathematics, feel self-confidence in mathematics, believe that they can learn mathematics, believe that mathematics improves their thinking skills," along with other objectives related to the content (MoNE, 2018). There are many studies in the literature that show self-efficacy has positive effects on mathematics achievement (Huang, 2013).

Mathematics course is perceived as a course where students are afraid of making mistakes, cannot ask for permission to speak and therefore fail (Altun, 2010). For this reason, students develop negative attitudes towards mathematics course and get into a vicious circle between failure and attitude (Primi et al., 2020). Bayturan (2004) describes attitude as one of the most important indicators of the affective characteristics of a course. Attitude is all of the positive or negative thoughts of an individual has towards her/his environment (Ozguven, 1999). It is stated that attitude that emerges as a result of the interactions of an individual is a permanent phenomenon that is acquired through the results of learning that affects the thoughts and directs the behaviors (Di Martino \& Zan, 2010; Freedman, Sears \& Carlsmith, 1993; Ulgen, 1995). In this respect, students' negative attitude towards mathematics course may cause failure that will last for years. In this regard, teachers have important responsibilities in developing a positive attitude towards mathematics. The important suggestions for the teachers are as follows: to prepare the activities organized for mathematics course by taking the development level of students into account, to give tasks that encourage them to research and question, to use materials related to conceptual learning, to tolerate the mistakes made, to prevent negative behaviors among peers, and to emphasize the fact that there are different ways to solve a problem (Altun, 2010).

This study aims to examine whether there is a relationship between abstract thinking skills, selfefficacy perceptions and attitude towards mathematics and how these variables predict mathematics achievement (MA). Although many studies have been conducted on abstract thinking skills, self-efficacy perceptions and attitude towards mathematics separately, it is thought that it will be useful to examine these three variables together with mathematics achievement. This study aimed to inform teachers and researchers and to contribute to the literature in terms of guiding them to develop studies for the positive development of abstract thinking skills, self-efficacy and attitude towards mathematics. Many attempts have been made to reduce inequality of opportunity in education caused by the ethnical, socio-economical, emigrational, etc. reasons in the world. (Curto \& Fryer, 2014). In this sense, in Turkey in 1962, "Regional Primary Boarding Schools" were founded to fulfill the needs of the children of the families living in in rural areas such as villages and small towns which do not have any schools, by also providing them shelter, food, water and clothing (Udum, 2012). The boarder students who continue their education at regional boarding secondary schools and stay in dormitories by being separated from their families for a long time and grow up with economic problems are 
tried to be brought to society (Birgin \& Demirkiran, 2017). The study is expected to contribute to the improvement of the quality of mathematics education at these schools. For this purpose, the following research questions were determined:

(1) Is there a significant relationship between secondary school students' abstract thinking skills, attitude towards mathematics, self-efficacy perceptions, and mathematics achievements?

(2) How do secondary school students' abstract thinking skills, self-efficacy perceptions and attitude towards mathematics predict their mathematics achievements?

(3) Do secondary school students' abstract thinking skills, self-efficacy perceptions, attitude towards mathematics, and mathematics achievements differ according to their school type and boarding status?

\section{Method}

\section{Research Model}

Relational screening model, which is a type of quantitative research method, was used in the study. Relational model is a model that aims to determine whether there is a relationship between two or more variables or the extent of the relationship (Cohen, Manion \& Morrison, 2000). In correlation-type relationship studies, it is tried to learn whether variables change by interacting with each other, if there is an interaction with each other, and if yes how this occurs. However, the relationship found is not interpreted as a cause-and-effect relationship but is considered as a factor affecting the variable (Karasar, 2005).

\section{Population and Sample}

The sample consists of 198 eighth-grade students selected from seven schools, in which five of them were secondary schools and two were regional boarding secondary schools from the East of Turkey. The study was conducted in the spring term of 2018-2019 academic year. Participants were selected by simple random sampling method. Participation of the study was based on volunteering. Students were from middle and lower income families. The distribution of the students participating in the study by gender and school type are presented in Table 1.

Table 1. Distribution of participants by school type and gender

\begin{tabular}{llll}
\hline School Type & Gender & & Total \\
\hline & F & M & \\
\hline Secondary School & 52 & 44 & 96 \\
Regional Boarding Secondary School & 56 & 46 & 102 \\
\hline Total & 108 & 90 & 198 \\
\hline
\end{tabular}

\section{Data Collection Tools}

The "Abstract Thinking Test in Mathematics" developed by Uysal-Kog and Baser (2012) was applied to reveal the abstract thinking skills of the students participating in the research. KR-20 reliability coefficient of the test was found to be 0.66 . The maximum score that can be gained in the test consisting of 18 items is 100. The "Mathematics Self-Efficacy Perception Scale" developed by Umay (2001) for the self-efficacy perceptions of the students participating in the study was used. The Cronbach-alpha reliability coefficient of the scale that consists of 14 items was calculated as 0.88 . In order to determine students' attitudes towards 
mathematics, "Mathematics Attitude Scale" developed by Nazlicicek and Erktin (2002) was used. This scale consists of 6 dimensions in total. In the research, the abbreviated form of the scale consisting of 3 dimensions was applied. Cronbach-alpha reliability coefficient of this applied form was found to be 0.84 . The maximum score that can be gained from the scale consisting of 20 items 8 of which is negative is 100 . Considering the reliability coefficients of the scales applied in the study, it can be said that the measurement tools are reliable. The mathematics achievement of the students was evaluated by taking the arithmetic average of the 1st and 2nd math exam results of the students in the e-School system of Ministry of National Education in the spring term of 2018-2019 academic year. The ranges of 0-44 (poor), 45-69 (moderate), 70-84 (good) and 85-100 (very good) were determined as evaluation criteria. Data collection tools were applied to the 8th grade students in 2 course hours (80 minutes).

\section{Data Analysis}

For the first sub-problem of the research, Pearson Correlation analysis was applied and for the second sub-problem, multiple regression analysis was applied. Finally, for the third subproblem of the research:

(1) Since the data on abstract thinking skills and attitude towards mathematics are not suitable for normal distribution in Mathematics $(p=.200>.05-p=.200>.05$, respectively), Mann Whitney-U test was applied in order to investigate whether there is a significant difference by gender. And Kruskal Wallis $\mathrm{H}$ test was applied to investigate whether there is a significant difference by school type;

(2) since the data on self-efficacy perception and mathematics achievement towards mathematics are suitable for normal distribution $(\mathrm{p}=.000<.05-\mathrm{p}=.000<.05$ respectively), independent variable sample t-test was applied to investigate whether there is a significant difference by gender. And one-way Anova test was used in order to investigate whether there is a significant difference by school type.

\section{Findings and Comments}

\section{Findings of the First Sub-Problem}

The statistics of the data obtained for abstract thinking skills, self-efficacy perceptions, attitude towards mathematics and mathematics achievement for the first sub-problem of the research are presented in Table 2.

Table 2. The statistics of the data obtained for abstract thinking skills, self-efficacy perceptions, attitude towards mathematics and mathematics achievement

\begin{tabular}{llll}
\hline & N & Mean & ss \\
\hline Abstract Thinking Skill & 198 & 44.88 & 18.64 \\
Self-efficacy Perception & 198 & 68.00 & 11.52 \\
Attitude towards Mathematics & 198 & 75.23 & 12.67 \\
\hline Mathematics Achievement & 198 & 58.65 & 23.58 \\
\hline
\end{tabular}

Correlation analysis results between students' abstract thinking skills, self-efficacy perceptions, attitudes towards mathematics and mathematics achievement are presented in Table 3. 
Table 3. Correlation analysis results between students' abstract thinking skills, self-efficacy perceptions and their attitudes towards mathematics

\begin{tabular}{llllll}
\hline & & ATS & SEP & ATM & MA \\
\hline ATS & $\mathrm{r}$ & 1 & .416 & .359 & .566 \\
& $\mathrm{p}$ &. & .000 & .000 & .000 \\
SEP & $\mathrm{r}$ & & 1 & .753 & .393 \\
& $\mathrm{p}$ & &. & .000 & .615 \\
ATM & $\mathrm{r}$ & & 1 & .404 \\
& $\mathrm{p}$ & & &. & .023 \\
\hline
\end{tabular}

According to the data obtained, it is seen that there is a positive, moderate $(\mathrm{r}=.416)$, significant relationship $(p=.000<.05)$ between students' abstract thinking skills and their self-efficacy perceptions; a positive, moderate $(\mathrm{r}=.359)$, significant relationship $(\mathrm{p}=.000<.05)$ between students' abstract thinking skills and their attitudes towards mathematics; and a positive, high $(\mathrm{r}=.753)$ significant relationship $(\mathrm{p}=.000<.05)$ between students' self-efficacy perceptions and their attitudes towards mathematics. In addition, there is a positive, moderate $(r=.566)$ significant relationship $(\mathrm{p}=.000<.05)$ between students' abstract thinking skills and their mathematics achievements; and a positive, moderate $(\mathrm{r}=.404)$ significant relationship $(\mathrm{p}=.023$ $<.05$ ) between students' mathematics achievements and their attitudes towards mathematics. There is a moderate $(r=.393)$ positive relationship between students' self-efficacy perceptions and their mathematics achievement, but this relationship was not statistically significant. Pallant (2015) stated that in order to perform multiple linear regression analysis, there should be at least 30 or more relationships between the predictive variables and the dependent variable. It can be seen that abstract thinking skills and attitude towards mathematics can be predictors of mathematics achievement.

\section{Findings of the Second Sub-Problem}

Findings for the second sub-problem were obtained by Multiple Linear Regression analysis. Statistics results are given in Table 4.

Table 4. Model summary predicted by mathematics achievement

\begin{tabular}{|c|c|c|c|c|c|c|c|}
\hline \multirow[t]{2}{*}{ Model } & \multirow{2}{*}{\multicolumn{2}{|c|}{$\mathrm{R}$}} & \multirow[t]{2}{*}{ Corrected } & \multirow[t]{2}{*}{ SS } & \multicolumn{3}{|c|}{ Statistics of Change } \\
\hline & & & & & Change & F Change & Significance \\
\hline 1 & $\begin{array}{l}.606 \\
a\end{array}$ & .367 & .357 & 18.902 & .367 & 37.520 & .000 \\
\hline
\end{tabular}

a. Determinants: (Stable), Self-efficacy towards Mathematics, Abstract Thinking Skill, Attitude Towards Mathematics

When Table 4 is analyzed, it is seen that independent variables explain $37 \%$ of the total variance of mathematics achievement. In other words, it can be said that at least one of the independent variables has a significant effect on the dependent variable $(\mathrm{p}=.000<.05)$.

Table 5. ANOVA table predicted by mathematics achievement

\begin{tabular}{|c|c|c|c|c|c|}
\hline \multicolumn{6}{|l|}{ ANOVA $^{\mathrm{a}}$} \\
\hline Model & Sum of Squares & $\mathrm{Sd}$ & Mean-Square & $\mathrm{F}$ & Sig. \\
\hline \multirow{3}{*}{$\begin{array}{ll}1 & \text { Regression } \\
& \text { Residual/Error } \\
& \text { Total } \\
\end{array}$} & 40218.702 & 3 & 13406.234 & 37.550 & $.000^{\mathrm{b}}$ \\
\hline & 69317.537 & 194 & 357.307 & & \\
\hline & 109536.239 & 197 & & & \\
\hline \multicolumn{6}{|c|}{ a. Dependent Variable: Mathematics Achievement } \\
\hline \multicolumn{6}{|c|}{$\begin{array}{l}\text { b. Determinants: (Stable), Self-efficacy towards Mathematics, Abstract Thinking Skill, Attitude } \\
\text { Towards Mathematics }\end{array}$} \\
\hline
\end{tabular}


ANOVA table should be examined in order to evaluate whether the predicted variables and the model of the predicting variables are statistically significant in the stepwise multiple regression analysis (Pallant, 2015). According to the Table 5, it is seen that the regression model created to determine the power of aforesaid independent variables to predict mathematics achievement is statistically significant $(\mathrm{F}=37.550, \mathrm{p}=.000<.05)$.

Table 6. Multiple regression analysis for predicting mathematics achievement

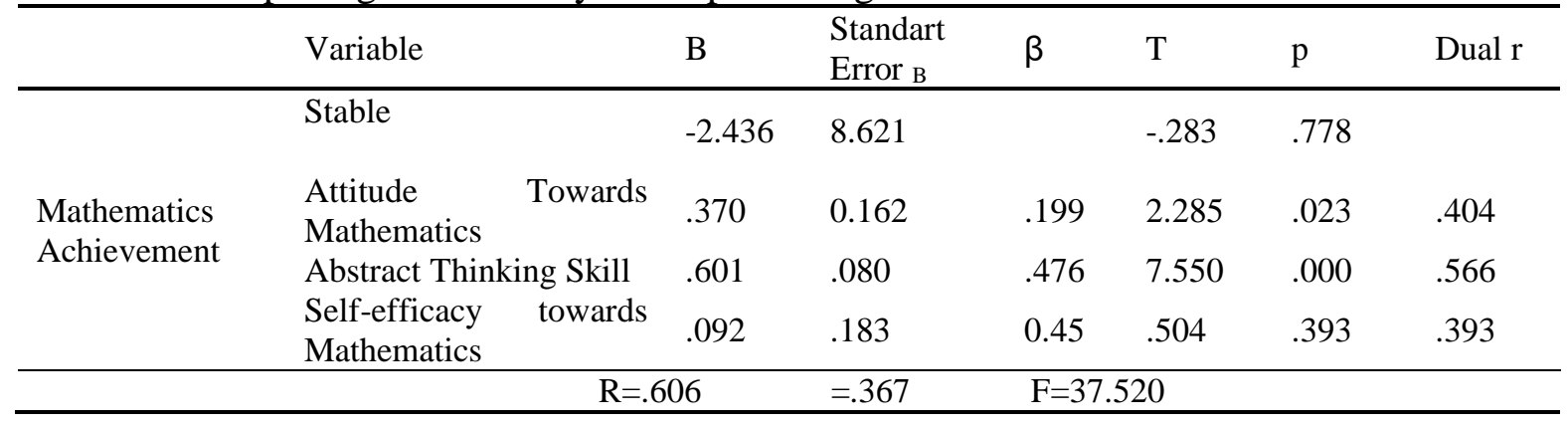

In Table 6, it is seen that students' attitudes towards mathematics and their abstract thinking skills are a significant predictor of their mathematics achievement and that three of them explained $37 \%$ of the variance together with self-efficacy perception $(F=37.52)$. Respectively, the Beta coefficient for the attitude variable towards mathematics was .199, the Beta coefficient for the abstract thinking skill variable was .476 , and the Beta coefficient for the self-efficacy variable was .45. While the $t$ values of the variables of attitude towards mathematics and abstract thinking skills were determined as statistically significant $(\mathrm{t}=2.285, \mathrm{t}=7.550, \mathrm{p}<0.05$, respectively); the $t$ value of the self-efficacy variable was not statistically significant $(t=.504$, $\mathrm{p}<0.05)$. Consequently, according to the regression analysis findings, the mathematical model for predicting mathematics achievement is as follows:

Mathematics Achievement $=-2.436+0.370 \mathrm{ATM}+0.601 \mathrm{ATS}+0.092 \mathrm{SEP}$.

\section{Findings of the Third Sub-Problem}

Table 7. Mann Whitney $U$ results of the data about abstract thinking and attitudes towards mathematics by school type

\begin{tabular}{lllllll}
\hline & & $\mathrm{N}$ & & $\mathrm{ss}$ & $\mathrm{Z}$ & $\mathrm{p}$ \\
\hline $\begin{array}{l}\text { Abstract } \\
\text { Thinking Skill }\end{array}$ & $\begin{array}{l}\text { Secondary } \\
\text { School }\end{array}$ & 96 & 49.58 & 18.45 & & \\
& $\begin{array}{l}\text { Regional } \\
\text { Boarding } \\
\text { Secondary } \\
\text { School }\end{array}$ & 102 & 40.46 & 17.82 & -3.212 & .001 \\
$\begin{array}{l}\text { Attitude } \\
\text { Towards }\end{array}$ & $\begin{array}{l}\text { Secondary } \\
\text { Mathematics }\end{array}$ & 96 & 78.80 & 11.28 & & \\
& $\begin{array}{l}\text { School } \\
\text { Regional } \\
\text { Boarding } \\
\text { Secondary } \\
\text { School }\end{array}$ & 102 & 71.88 & 13.05 & & \\
& & & & & \\
& & & & & \\
\hline
\end{tabular}

As can be seen from the Table 7, students' abstract thinking skills differ significantly $(=49.58)$ in favor of the students studying at secondary school $(\mathrm{p}=.001<.05)$. According to the type of 
school, for the scores that the students gained at the mathematics attitude scale, it is seen that there is a significant difference $(\mathrm{p}=.000<.05)$ in favor of the students studying at secondary school $(=78.80)$.

Table 8. t-test results of self-efficacy perception towards mathematics and mathematics achievement by school type

\begin{tabular}{lllllll}
\hline & & $\mathrm{N}$ & & $\mathrm{ss}$ & $\mathrm{t}$ & $\mathrm{p}$ \\
\hline $\begin{array}{l}\text { Self-efficacy } \\
\text { perception } \\
\text { towards }\end{array}$ & $\begin{array}{l}\text { Secondary } \\
\text { Mathematics }\end{array}$ & 96 & 70.95 & 10.78 & & \\
& $\begin{array}{l}\text { Regional } \\
\text { Boarding } \\
\text { Secondary }\end{array}$ & 102 & 65.22 & 11.57 & 3.598 & .000 \\
School & & & & & \\
Mathematics & $\begin{array}{l}\text { Secondary } \\
\text { Achievement }\end{array}$ & 96 & 59.40 & 25.17 & & \\
& $\begin{array}{l}\text { School } \\
\text { Regional } \\
\text { Boarding } \\
\text { Secondary } \\
\text { School }\end{array}$ & 102 & 57.96 & 22.08 & & .629 \\
& & & & & \\
\hline
\end{tabular}

When Table 8 is analyzed, according to school type, it is seen that the students' self-efficacy perceptions towards mathematics differ significantly $(\mathrm{p}=.000<.05)$ in favor of students studying at secondary school $(=70.95)$, but the difference between their mathematics achievement scores is not statistically significant $(\mathrm{p}=.669>.05)$.

Table 9. One-way Anova test results of mathematics achievement by boarding status

\begin{tabular}{llllll}
\hline School Type & N & & ss & F & p \\
\hline Daytime at RBS & 45 & 62.73 & 22.20 & & \\
Boarder at RBS & 57 & 54.19 & 24.43 & 1.775 & .176 \\
Daytime at Secondary School & 96 & 59.40 & 25.17 & & \\
\hline
\end{tabular}

As seen in Table 9, no significant difference was detected regarding the mathematics achievement between the groups determined according to the boarding status of students $(\mathrm{p}=$ $.176>.05)$.

Table 10. One-way Anova test results of self-efficacy perception towards mathematics by boarding status

\begin{tabular}{|c|c|c|c|c|c|}
\hline School Type & $\mathrm{N}$ & & ss & $\mathrm{F}$ & $\mathrm{p}$ \\
\hline Daytime at RBS & 45 & 63.97 & 13.16 & & \\
\hline Boarder at RBS & 57 & 66.22 & 10.16 & 6.981 & .001 \\
\hline Daytime at Secondary School & 96 & 70.95 & 10.78 & & \\
\hline
\end{tabular}

According to the Table 10, there is a significant difference $(\mathrm{p}=.001>.05)$ between at least two groups determined according to the boarding status of students about self-efficacy perceptions. The Scheffe test was carried out to determine between which group(s) the difference was. 
Table 11. Scheffe test results of self-efficacy perception towards mathematics according to the boarding status

\begin{tabular}{lllll}
\hline Group (I) & Group (J) & Difference (I-J) & Standard Error & p \\
\hline Daytime at RBS & Boarder at RBS & -2.25 & 2.23 & .603 \\
& $\begin{array}{l}\text { Daytime at Secondary } \\
\text { School }\end{array}$ & -6.98 & 2.02 & .003 \\
Boarder at RBS & Daytime at RBS & 2.25 & 2.23 & .603 \\
& $\begin{array}{l}\text { Daytime at Secondary } \\
\text { Daytime at }\end{array}$ & -4.74 & 1.87 & .043 \\
School & Boarder at RBS & 4.74 & 1.87 & .043 \\
\hline
\end{tabular}

When Table 11 is analyzed, it is seen that there is a significant difference between the selfefficacy perception scores of the daytime students studying at secondary school and the selfefficacy perception scores of the boarder students at regional boarding secondary school $(\mathrm{p}=$ $.043<.05$ ); and between the self-efficacy perception scores of the daytime students studying at secondary school and the self-efficacy perception scores of the daytime students studying at regional boarding secondary school $(\mathrm{p}=.003<.05)$. The level of the significance obtained by the Scheffe test is shown in Table 12.

Table 12. Significance level of self-efficacy perception according to boarding status towards mathematics

\begin{tabular}{llll}
\hline Boarding Status of Students & & \multicolumn{2}{l}{ Significance Level $=0.05$} \\
\cline { 3 - 4 } & $\mathrm{N}$ & 1 & 2 \\
\hline Daytime at RBS & 45 & 63.9687 & \\
Boarder at RBS & 57 & 66.2156 & 66.2156 \\
Daytime at Secondary & 96 & & 70.9526 \\
School & & .549 & .071 \\
Significance & & & \\
\hline
\end{tabular}

According to Table 12, the self-efficacy perceptions towards mathematics scores of the daytime students studying at secondary school $(=70.95)$ were determined to be higher than those of the boarder students at regional boarding secondary school $(=66.22)$ and higher than those of the daytime students studying at regional boarding secondary school $(=63.97)$. This result shows that there is a significant difference in favor of daytime students studying at secondary school regarding their self-efficacy perception scores towards mathematics.

Table 13. Kruskal Wallis test results of students' abstract thinking skill scores according to their boarding status

\begin{tabular}{|c|c|c|c|c|c|c|}
\hline Groups & $\mathrm{N}$ & $\begin{array}{l}\text { Mean } \\
\text { Rank }\end{array}$ & $\mathrm{Sd}$ & & $\mathrm{p}$ & Significant Difference \\
\hline Daytime at RBS & 45 & 112.92 & & & & \\
\hline Boarder at RBS & 57 & 94.96 & 2 & 11.938 & .003 & $\begin{array}{l}\text { Day. at RBS-Day. at } \\
\text { Secondary Sch. }\end{array}$ \\
\hline $\begin{array}{l}\text { Daytime at Secondary } \\
\text { School }\end{array}$ & 96 & 80.48 & & & & \\
\hline
\end{tabular}

As seen from the findings in the Table 13, the difference between students' abstract thinking skills scores was found statistically significant $(\mathrm{p}=.003<.05)$. Since the abstract thinking skills scores of boarder students $(=80.48)$ at the regional boarding secondary school are lower than the abstract thinking skills scores of daytime students $(=112.92)$ at secondary school, the significance is in favor of the daytime students studying at the regional boarding secondary school. 
Table 14. Kruskal Wallis test results of attitude towards mathematics by the boarding status

\begin{tabular}{|c|c|c|c|c|c|c|}
\hline Groups & $\mathrm{N}$ & $\begin{array}{l}\text { Mean } \\
\text { Rank }\end{array}$ & Sc & & $\mathrm{p}$ & Significant Difference \\
\hline Daytime at RBS & 45 & 116.04 & & & & $\begin{array}{l}\text { Day. at RBS-Day. at } \\
\text { Secondary Sch. }\end{array}$ \\
\hline Boarder at RBS & 57 & 82.30 & 2 & 15.613 & .000 & $\begin{array}{l}\text { Boar. at RBS-Day. at } \\
\text { Secondary Sch. }\end{array}$ \\
\hline $\begin{array}{l}\text { Daytime at Secondary } \\
\text { School }\end{array}$ & 96 & 85.22 & & & & \\
\hline
\end{tabular}

When Table 14 is analyzed, it is seen that the scores of students' attitudes towards mathematics differ significantly according to the boarding status of the students $(\mathrm{p}=.000<.05)$. According to the results obtained, the attitude scores of daytime students $(=85.22)$ at the regional boarding secondary school are lower than the attitude scores of the daytime students $(=116.04)$ at the secondary school. In addition, it is observed that the attitude scores of the boarder students (= $82.30)$ at the regional boarding secondary school are lower than the attitude scores $(=116.04)$ of daytime students at secondary school. Therefore, it is understood that the significance is in favor of the daytime students studying at secondary school.

\section{Discussion}

This study investigated whether there is a relationship between abstract thinking skills, self-efficacy perceptions and attitude towards mathematics and how these variables predicted mathematics achievement. According to the findings, a moderate positive correlation was found between abstract thinking skills and self-efficacy perceptions for the first sub-problem of the study. Accordingly, it can be said that when students' abstract thinking skills develop more, their self-efficacy perceptions towards mathematics will increase more. Smith, Wigboldus and Dijksterhuis (2008), in their study in the field of social psychology, stated that abstract thinking ability makes individuals feel stronger. Individuals' own sense of power determines which goals are acceptable (Keltner, Gruenfeld \& Anderson, 2003). It can be said that people who feel strong have a belief that they have the necessary knowledge and skills in the process of achieving the determined goals emphasized in the definition of self-efficacy. In this regard, it can be stated that the findings obtained from this study are compatible with the findings of Smith, Wigboldus and Dijksterhuis (2008) study. There is also a similar situation for this study between abstract thinking skills and attitude towards mathematics. According to this, it can be said that when students' abstract thinking skills increase more, their attitudes towards mathematics will develop more positively. These results can be said to be parallel with the results in studies that concluded that there is a positive relationship between abstract thinking skills and attitude towards mathematics (Aljaberi, 2014; Kargar, Tarmizi \& Bayat, 2010; UysalKog \& Baser, 2012). According to the findings, the relationship between students' self-efficacy perceptions and their attitudes towards mathematics is also seen to be positive. Falco (2019) also explained that when secondary school students' self-efficacy perceptions towards mathematics are ensured to be positive, it will contribute them to develop positive attitude towards mathematics. In addition to this, it is also compatible with the results of Yagmur's (2012) and Yilmaz's (2011) studies, which indicated that there is a positive relationship between self-efficacy perceptions and attitude towards mathematics.

Based on the findings obtained for the second sub-problem, it was determined that the variables of attitude towards mathematics, abstract thinking skills and self-efficacy towards mathematics explained $37 \%$ of the total variance in mathematics achievement. According to the findings, when the variable of self-efficacy towards mathematics is compared with the other two 
variables, it was seen that it does not have a significant effect in predicting mathematics achievement. However, the variables of abstract thinking skills and attitude towards mathematics are seen important predictors of mathematics achievement. There are many studies in the literature indicating that attitude towards mathematics, self-efficacy perceptions and abstract thinking skills are related to mathematics achievement (Kablan \& Suzer Ugur, 2020; Ma \& Xu, 2004; Stevens et al., 2004; Roick \& Ringisen, 2018; Uysal-Kog \& Baser, 2012). The finding that the variables of abstract thinking skills and attitude towards mathematics have a partially high effect in explaining mathematics achievement coincides with the results of the studies in the literature. However, it was seen in this study that self-efficacy perception has a remarkably low effect in explaining mathematics achievement compared to the results obtained from the studies in the literature. The reason for this result may be due to the socio-economic status of the sample group in the study. As a matter of fact, the self-efficacy perceptions of boarder students studying at regional boarding secondary schools were found lower than the daytime students studying at secondary schools. The reason of self-efficacy perception's not being a significant predictor according to the findings obtained may be the factors such as the majority of the study group's being away from their families, negative dormitory environment and poor socio-economic status of students' families.

According to the findings for the third sub-problem of the study, when the abstract thinking skills scores are examined, it is seen that the scores of the students studying at secondary school are higher than the scores of the students studying at regional boarding secondary school. There is no study found studying the abstract thinking skills of the students studying especially at boarding schools in the literature. However, it has been stated that students coming from families with poor socio-economic status living in rural areas are disadvantaged in terms of academic success, cognitive and emotional developments (Brooks-Gunn, Duncan, \& Maritato, 1999). In this regard, since the boarder students studying at regional boarding secondary schools may have higher emotional load than not boarder students, their abstract thinking skill scores may be lower. It was determined that the attitudes of students towards mathematics differed in favor of students studying daytime at secondary school, according to the school type. Wasike (2013), in his study that he conducted at boarding schools and daytime schools in Kenya, concluded that the students' mathematics attitudes and academic achievements differed in favor of students studying at boarding schools. However, considering the types of schools for Kenya, families with good socio-economic status send their children to boarding schools and children who come from economically disadvantaged families are sent to daytime schools whose expenses are covered by the state (Amunga \& Musasia, 2011). This is the exact opposite situation in the context of school types in Turkey. In this regard, it can be said that the results regarding the attitudes towards mathematics obtained from the study is compatible with the results obtained by Wasike (2013). Considering the self-efficacy scores, it was found that the students studying at secondary school had higher self-efficacy perceptions than the students studying at boarding school. The reason for this may be the emotional factors caused by the fact that students are staying away from their families in the dormitory environment. Reyes and Stanic (1988) stated that social effects will affect students' attitudes towards mathematics. Similarly, it was stated that social control, social capital, perception of opportunity and neighborhood have a significant impact on the learning outcomes (Ainsworth, 2002). For this reason, the scores of abstract thinking skills, attitude towards mathematics and self-efficacy perceptions may be lower for the boarder students at boarding schools. No significant difference between the mathematics achievement scores of the students in the study group is spotted. As stated before, students at boarding schools continue their education lives with the economic difficulties and many problems they need to overcome without the support of their families (Birgin \& Demirkiran, 2017). In this case, it can be said that the fact that these students are 
under more financial and moral burden than the other students may negatively affect their mathematics achievements. However, contrary to this expectation, no difference was found in students' mathematics achievements between standard school and boarding school. Some reasons such as compulsory homework studies after school programs at boarding schools, the coaching of teachers who stayed with the students as coaches and the fact that students had the opportunity to study with their peers may have balanced this difference. As a matter of fact, Dobbie and Fryer (2011) stated that qualified schools became effective to close the gap related to mathematics achievement between the students who come from families with low socioeconomic status and the students in better conditions and these schools increased the success of the students who experienced economic difficulties. It can be said that the results obtained in this regard are parallel to the results in the literature.

\section{Conclusion and Suggestions}

As a result, it was concluded that abstract thinking skills, self-efficacy and attitude towards mathematics, which are the factors affecting mathematics achievement, are related to each other and these factors have an important effect on explaining mathematics achievement. In addition, it can be said that the boarding situation negatively affects the self-efficacy perceptions, mathematics attitudes and abstract thinking skills of the students. However, there is no significant difference between their mathematics achievements, so it can be stated that if negativities are eliminated along with other factors affecting achievement, the boarder students might be more successful. In this context, according to the results of the study, the following suggestions have been given:

- If the variables of abstract thinking skills, attitude towards mathematics, and selfefficacy perception towards mathematics are taken into consideration in classroom activities, learning outcomes can be affected positively.

- Dormitories belonging to regional boarding schools can be developed to contribute more to the needs and personal characteristics of the boarder students and efforts can be made to eliminate negative conditions. In this sense, it can be said that providing social and sportive activities will be beneficial, along with healthy study environments and other environments where the students can express themselves better and feel comfortable.

- This study was conducted with 8th grade students. It may be useful to conduct similar studies at different grade levels.

- Similarly, it may be useful to conduct similar studies with different regional boarding secondary schools of different regions by comparing them with each other and secondary schools out of the region.

\section{Acknowledgement}

This study has been produced from the master's thesis of the second author that conducted under the supervision of the first author.

\section{References}

Agaç, G. (2013). 8. Sinıf ögrencilerinin matematiğe yönelik; problem çözme, soyut düşünme, inanç, öğrenilmiş çaresizlik puanlarının bazı değişkenler açısından incelenmesi ve aralarindaki ilişki [The investigation of and the interrelationship among 8th grade students problem solving skills, beliefs, learned helplessness and abstract thinking 
scores in mathematics in terms of certain variables]. (Unpublished Master's Thesis), Sakarya University, Sakarya.

Ainsworth, J.W. (2002). Why does it take a village? The mediation of neighborhood effects on educational achievement. Social Forces, 81, 117-152. https://doi.org/10.1353/sof.2002.0038

Akdemir, O. (2006). İlköğretim öğrencilerinin matematik dersine yönelik tutumları ve başarı güdüsü [Elementary students' attitudes towards mathematics lesson and achievement motivation]. (Unpublished Master's Thesis), Dokuz Eylul University, Izmir.

Akyuz, G. (2014). The effects of student and school factors on mathematics achievement in TIMSS 2011. Education and Science, 39(172), 150-162.

Alci, B. Erden, M. \& Baykal, A. (2010 ) . Explanatory and predictive pattern of university students' mathematics achievement and their perceived problem solving abilities, selfefficacy perceptions, metacognitive self-regulation strategies, and national university entrance examination. Bogazici University Journal of Education, 25(2), 53-68.

Aljaberi, N. M (2014). Pre-service elementary school teachers' level of mathematical thinking and their attitudes toward mathematics. Journal of Education and Human Development, 3(3), 181-195. https://doi.org/10.15640/jehd.v3n3a15

Altun, M. (2010). Matematik Ögretimi [Teaching Mathematics]. Bursa: Alfa Aktuel Publication.

Amunga, J.K. \& Musasia, A.M. (2011). Disparities in mathematics achievement among secondary schools: the case of Kenya. Problems of Education in the 21st Century, 28, 8-18.

Ayguner, E. (2016). Sekizinci sinıf ögrencilerinin görsel matematik okuryazarlı̆̆ı öz yeterlik algıları ile gerçek performanslarının karşılaştırılması [A comparison of eight grade students' self-efficacy perception of visual mathematics literacy and their actual performance]. (Unpublished Master's Thesis), Eskisehir Osmangazi University, Eskisehir.

Bandura, A. (1997) Self-efficacy: the exercise of control. New York: W. H. Freeman and Company.

Bayturan, S. (2004). İlköğretim ikinci kademe öğrencilerinin matematik başarılarının matematiğe yönelik tutum, psikososyal ve sosyodemografik özellikleriyle ilişkisi [The relationship between mathematics achievement and attitude towards mathematics, psychosocial and socio-demographic features in second level students of primary ecucation]. (Unpublished Master's Thesis), Dokuz Eylul University, İzmir.

Birgin, O. \& Demirkan, H. (2017). Investigation of regional boarding secondary school students' attitudes towards mathematics according to some variables. E-International Journal of Educational Research, 8(2), 1-15. https://doi.org/10.19160/ijer.281765

Brooks-Gunn, J., Greg J. Duncan, G. J. \& Maritato, N. (1999). Poor families, poor outcomes: The well-being of children and youth. In Greg J. Duncan and Jeanne Brooks- Gunn (Eds.) Consequences of growing up poor (pp. 1-17). New York: Russell Sage Foundation.

Casillas, A., Robbins, S., Allen, J., Kuo, Y.-L., Hanson, M. A., \& Schmeiser, C. (2012). Predicting early academic failure in high school from prior academic achievement, psychosocial characteristics, and behavior. Journal of Educational Psychology, 104(2), 407-420. https://doi.org/10.1037/a0027180

Curto, V. E., \& Fryer, R. G. (2014). The Potential of Urban Boarding Schools for the Poor Evidence from SEED. Journal of Labor Economics 32(1), 65-93. https://doi.org/10.1086/671798

Celik, N. (2012). Matematik ögretmen adaylarının ve ögretmenlerinin öz düzenleme becerilerinin ve öz-yeterlik algllarının incelenmesi [Investigation of self-regulation 
skills and self-efficacy perceptions of prospective mathematics teachers and teachers]. (Unpublished Master's Thesis), Ataturk University, Erzurum.

Cohen, L., Manion, L., \& Morrison, K. (2000). Research methods in education. London: Routledge Falmer.

Di Martino, P., \& Zan, R. (2010). 'Me and maths': Towards a definition of attitude grounded on students' narratives. Journal of Mathematics Teacher Education, 13(1), 27-48. https://doi.org/10.1007/s10857-009-9134-z.

Dobbie, W. \& Fryer, R.G. (2011). Are high-quality schools enough to increase achievement among the poor? Evidence from the Harlem children's zone. American Economic Journal Applied Economics, 3(3), 158-187. https://doi.org/10.1257/app.3.3.158

Dreyfus T. (2020) Abstraction in Mathematics Education. In: Lerman S. (eds) Encyclopedia of Mathematics Education (pp. 13-16). Cham: Springer.

Falco, L. D. (2019) An intervention to support mathematics self-efficacy in middle school. Middle School Journal, 50(2), 28-44. https://doi.org/10.1080/00940771.2019.1576580

Freedman, J. L., Sears, D. O., \& Carlsmith, J. M. (1993). Social Psychology (Trans: A. Donmez). Ankara: Imge Kitabevi.

Hackett, G. \& Betz, N. E. (1989). An exploration of the mathematics self-efficacy / mathematics performance correspondence. Journal for Research Mathematics Education, 20( 3), 261-273.

Hoy, W. K., \& Woolfolk, A. E. (1993). Teachers' sense of efficacy and the organizational health of schools. The Elementary School Journal, 93, 355-372. http://dx.doi.org/10.1086/461729

Huang, C. (2013). Gender differences in academic self-efficacy: a meta-analysis. Eur J Psychol Educ 28, 1-35. https://doi.org/10.1007/s10212-011-0097-y

Kablan, Z. \& Suzer Ugur, S. (2020). The relationship between routine and non-routine problem solving and learning styles. Educational Studies. https://doi.org/10.1080/03055698.2019.1701993

Karasar, N. (2005). Bilimsel Araştırma Yöntemi [Scientific Research Method] (15th Edition). Ankara: Nobel Publication.

Kargar, M., Tarmizi, R.A., \& Bayat, S. (2010). Relationship between mathematical thinking, mathematics anxiety and mathematics attitudes among university students. Procedia Social and Behavioral Sciences, 8(1), 537-542. https://doi.org/10.1016/j.sbspro.2010.12.074

Keltner, D., Gruenfeld, D. H., \& Anderson, C. (2003). Power, approach, and inhibition. Psychological Review, 110, 265-284.

Kilic, S. \& Demir, İ. (2010). Usıng pısa 2003, examınıng the factors affectıng students' mathematics achievement. H. U. Journal of Education, 38, 44-54.

Ma, X., \& Xu, J. (2004). Determining the causal ordering between attitude toward mathematics and achievement in mathematics. American journal of education, 110(3), 256-280.

MoNE (Ministry of National Education) (2018). Primary and Secondary School Mathematics Course (Year 1, 2, 3, 4, 5, 6, 7 and 8) Curriculum. Ankara: MoNE.

National Council of Teachers of Mathematics [NCTM], (2000). Principles and standards for school mathematics. Reston, VA: National Council of Teachers of Mathematics.

Erktin, E., \& Nazlicicek, N. (2002). The Shortened Mathematics Attitude Scale for Primary School Mathematics Teachers. V. National Science and Mathematics Education Congress, 860- 865.

OECD (2007). PISA 2006: Science competencies for tomorrow's world. Volume 1: Analysis. Paris: OECD.

Ozdemir, E., \& Gur, H. (2011). Validity and Reliability Study of Mathematics AnxietyApprehension Survey (MASS). Education and Science, 36(161), 39-50. 
Ozguven, I. E. (1999). Psikolojik Testler [Psychological Tests]. Ankara: PDREM Publications.

Ozmantar, M. F. (2005). An investigation of the formation of mathematical abstractions through scaffolding (Doctoral dissertation). University of Leeds, Leeds.

Pallant, J. (2015). SPSS Survival Manual. Berkshire: Open University Press.

Pantziara, M. (2016). Student self-efficacy beliefs. In G. A. Goldin, M. S. Hannula, E. HeydMetzuyanim, A. Jansen, R. Kaasila, S. Lutovac, P. DiMartino, F. Morselli, J. A. Middleton,M. Pantziara, \& Q. Zhang (Eds.) Attitudes, beliefs, motivation, and identity in mathematics education (pp. 7-11). Heidelberg: Springer.

Peker, M. \& Mirasyedioglu, S. (2003). Relationship between second grade high school students' attitudes towards mathematics and mathematics achievement. Pamukkale University Journal of Education, 2(14), 157-166.

Piaget, J. (2001). Studies in reflecting abstraction (ed and trans: Campbell RL). London: Psychology Press. (Original work published 1977).

Primia, C., Bacherinia, A., Beccaria, C. \& Donati, M. A. (2020). Assessing math attitude through the Attitude Toward Mathematics Inventory - Short form in introductory statistics course students. Studies in Educational Evaluation, 64, 1-9. https://doi.org/10.1016/j.stueduc.2020.100838

Reyes, L. H. \& Stanic, G. M. A (1988). Race, sex, socioeconomic status and mathematics. Journal for Research in Mathematics Education, 19, 26-43.

Roick, J., \& Ringeisen, T. (2018). Students' math performance in higher education: Examining the role of self-regulated learning and self-efficacy. Learning and Individual Differences, 65, 148-158. https://doi.org/10.1016/j.lindif.2018.05.018

Schunk, D. H. (1987). Peer models and children's behavioral change. Review of Educational Research, 57(2), 149-174. https://doi.org/10.3102/00346543057002149

Smith, P. K., Wigboldus, D. H. J., \& Dijksterhuis, A. (2008). Abstract thinking increases one's sense of power. Journal of Experimental Social Psychology, 44(2), 378-385. https://doi.org/10.1016/j.jesp.2006.12.005

Stevens, T., Harris, G., Aguirre-Muñoz, Z., \& Cobbs, L. (2009). A case study approach to increasing teachers' mathematics knowledge for teaching and strategies for building students' maths self-efficacy. International Journal of Mathematical Education in Science and Technology, 40(7), 903-914.

Udum, C. (2012). Normal ilköğretim okulu ve yatılı ilköğretim bölge okullarının SBS puanına göre matematik başarı düzeylerinin bazı değişkenler açısından incelenmesi [Review of students? achiment levels in maths tests of SBS exam between General primary schools and Boarding region primary schools]. (Unpublished Master's Thesis), Firat Universty, Elazig.

Ulgen, G. (1995). Ĕ̆itim Psikolojisi: Birey ve Öğrenme [Educational Psychology: Individual and Learning]. Ankara: Bilim Publications.

Umay, A. (2001). The effect of the primary school mathematics teaching program on the mathematics self-efficacy of students. Journal of Qafqaz University, 8(1), 1-8.

Usher, E. L. (2009). Sources of middle school students' self-efficacy in mathematics: A qualitative investigation. American Educational Research Journal, 46(1), 275-314. https://doi.org/10.3102/0002831208324517

Uysal Kog, O. \& Baser, N. E. (2012). The Role of Visualization Approach on Students' Attitudes Towards and Achievements in Mathematics. Elementary Education Online, 11(4), 945-957.

Van Oers, B. (2001). Contextualisation for abstraction. Cognitive Science Quarterly, 1(3), 279305. 
Wasike, A. (2013). Effects of attitudes of female students on the performance in mathematics in various types of secondary schools in teso district, Kenya. Journal of Education and Practice, 4(11), 119-131.

Yagmur, A. (2012). Anadolu ögretmen liselerinde ögrenim gören ögrencilerin matematik dersine yönelik tutumlart ile öz-yeterlilikleri arasindaki ilişki [The relationship between students' who are educated in Anatolian teacher high school attitudes to mathematics and students' self-competence]. (Unpublished Master's Thesis), Ahi Evran University, Kirsehir.

Yilmaz, C. (2011). 6, 7 ve 8. sınıf ögrencilerinin matematik güdüsü, kaygısı, öz yeterlik inancı ve öz kavramı ile matematik dersine yönelik tutumları arasındaki ilişkiler: Şereflikoçhisar örneği [Investigating relationships among mathematics motivation, anxiety, self-efficacy beliefs, self-concept and attitudes of sixth, seventh and eighth grade students for mathematics course: Sereflikochisar sample]. (Unpublished Master's Thesis), Ankara University, Ankara.

Yesildere, S. (2006). Farkl matematiksel güce sahip ilkögrretim 6, 7 ve 8 sinıf ögrencilerinin matematiksel düşünme ve bilgiyi oluşturma süreçlerinin incelenmesi [The investigation of mathematical thinking and knowledge construction processes of primary 6, 7 and 8th grade students who have different mathematical power]. (Unpublished Doctoral Thesis), Dokuz Eylul University, İzmir.

Yurt, S. \& Sunbul, A. M. (2014). A Structural Equation Model Explaining 8th Grade Students' Mathematics Achievements. Educational Sciences: Theory \& Practice, 14(4), 16421652. https://doi.org/10.12738/estp.2014.4.2193

Zuffiano, A., et al. (2013). Academic achievement: the unique contribution of self-efficacy beliefs in self-regulated learning beyond intelligence, personality traits, and self-esteem. Learning and Individual Differences, 23, 158-162. 